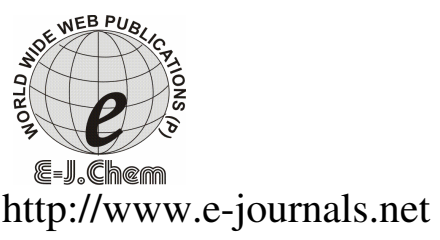

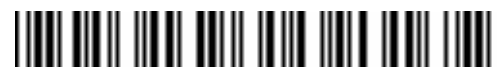 \\ ISSN: 0973-4945; CODEN ECJHAO \\ E-Journal of Chemistry
}

Vol. 4, No.1, pp 39-45, January 2007

\section{Transition Metal Complexes of Methyl- quinolino[3,2-b][1,5]benzodiazepine and Methylquinolino [3,2-b][1,5]benzoxazepine: Synthesis, Characterisation and Antimicrobial Studies}

\author{
B. BASAVARAJU*, H.S. BHOJYA NAIK ${ }^{\#}$, M.C. PRABHAKARA ${ }^{\#}$ \\ *Department of Biotechnology, GM Institute of Technology, Davangere-577 006, \\ Karnataka, India. Phone: 08192 233377, e-mail: basavaraju_b@yahoo.co.in \\ \#Department of PG studies and Research in Industrial Chemistry, \\ School of Chemical Sciences, Kuvempu University, Shankaraghatta-577 451, Shimoga, \\ Karnataka, India. Phone: 08282 256303, e-mail: hsb_naik@rediffmail.com
}

Received 31 September 2006; Accepted 8 September 2006

\begin{abstract}
The synthesis and characterisation of title complexes of the ligand Methylquinolino[3,2-b][1,5]benzodiazepine (MQBD) and Methylquinolino[3,2-b][1,5]benzoxazepine (MQBO) are reported. The complexes have been characterized by elemental analysis, molar conductance, magnetic studies, IR, ${ }^{1} \mathrm{H}$ NMR and UV-visible studies. They have the stoichiometry $\left[\mathrm{ML}_{2} \mathrm{Cl}_{2}\right]$ where $\mathrm{M}=\mathrm{Co}(\mathrm{II}) / \mathrm{Ni}(\mathrm{II}), \mathrm{L}=\mathrm{MQBD} / \mathrm{MQBO}$ and $\left[\mathrm{MLCl}_{2}\right]$ where $\mathrm{M}=\mathrm{Zn}(\mathrm{II}) / \mathrm{Cd}(\mathrm{II}), \mathrm{L}=\mathrm{MQBD} / \mathrm{MQBO}$. The antibacterial and antifungal activity of the metal complexes has been investigated.
\end{abstract}

Keywords: Antimicrobial activity, magnetic moment, quinoline, Methylquinolino[3,2-b][1,5]benzodiazepine and Methylquinolino[3,2b] $[1,5]$ benzoxazepine

\section{Introduction}

Quinoline derivatives represent the major class of heterocycles, and a number of preparations have been known from the late 1980s. The quinoline skeleton is often used for the design of many synthetic compounds with diverse pharmacological properties. The 8(diethylaminohexylamino)-6-methoxy-4-methyl-quinoline is highly effective against the protozoan parasite Trypanosoma cruzy, which is the agent of Chagas' disease ${ }^{1}$ and the 2-(2methylquinolin-4-ylamino)-N-phenylacetamide is more active than the standard antileishmanial drug sodium antimony gluconate ${ }^{2}$. The centipede, Scolopendra Subspines 
mutilalns L. which is found to contain 3,8-dihydroxyquinoline called Jineol has been prescribed for tetanus, childhood convulsions and acute heart attack ${ }^{3}$. Cryptolepine (5methyl-5H-indolo[3,2-b]quinoline) displays a plenty of pharmacological effects, such as antimuscarinic, noradrenergic receptor antagonistic, antihypertensive, vasodilative, antithrombotic, antipyretic and anti-inflammatory properties. Neocryptolepine and cryptolepine derivatives reveal antiplasmodial and antitrypanosomal and first of all, cytotoxic activities $^{4-6}$. Quinoline containing drugs particularly 4-aminoquinolines, have a long and successful history as antimalarials ${ }^{7,8}$.

\section{Experimental}

\section{Materials}

All the chemicals used in the present study are of AR grade. 2-Chloro-6-methylquinoline-3carbaldehyde (Sigma-Aldrich Chemie, Germany), 2-aminophenol (S.D.Fine Chem Ltd, India) and $o$-Phenylenediammine (S.D.Fine Chem Ltd, India) were used.

\section{Measurements}

The IR spectra of ligand and its metal complexes were recorded on a SHIMADZU FTIR-8400S spectrometer with $\mathrm{KBr}$ pellets in the region $250-4000 \mathrm{~cm}^{-1}$. JEOL $60 \mathrm{MH}_{\mathrm{Z}}$ spectrometer was used for recording the proton NMR spectra employing TMS as internal reference and DMSO- $\mathrm{d}_{6}$ as solvent. UV-visible spectra were measured on a SHIMADZU double beam spectrophotometer using N,N'-dimethylformamide as a solvent at $10^{-3} \mathrm{M}$ concentration.

\section{Antibacterial activity}

Antibacterial activity of ligands and its complexes were studied against Gram positive bacteria $S$. aureus and Gram negative bacteria $P$. aerugenosa by employing paper disc method $^{9}$. The streptomycin $(100 \mathrm{mg})$ was used as a standard. For each concentration, the mean diameter of inhibition zone developed $(\mathrm{mm})$ was calculated.

\section{Antifungal activity}

The antifungal studies of ligands and its complexes were tested on the fungal strains namely, C. albicans, A. flavus and A. niger in the growth media by using Batemann poisoned food technique ${ }^{10}$. The average percentage inhibition was calculated by using the reported method ${ }^{11}$. Synthesis of Methylquinolino[3,2-b][1,5]benzodiazepine(MQBD)

The mixture of 2-Chloro-6-methylquinoline-3-carbaldehyde (1.569 g, $5 \mathrm{mmo1})$ dissolved in small amount of acetic acid and $o$-Phenylenediammine $(0.541 \mathrm{~g}, 5 \mathrm{mmol})$ was taken in a 100 $\mathrm{ml}$ borosil beaker and a pinch of potassium iodide was then added. The whole mixture was made into slurry and was irradiated by placing the beaker in a microwave oven for about 10 minutes. The product obtained was poured into ice-cold water, the solid separated was filtered, dried and recrystallized (Scheme 1).

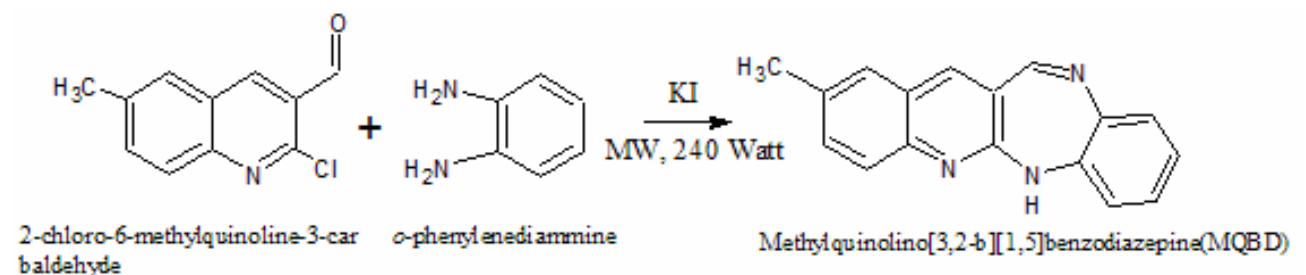

Scheme-1. Preparation of Methylquinolino[3,2-b][1,5]benzodiazepine(MQBD) 


\section{Synthesis of Methylquinolino[3,2-b][1,5]benzoxazepine (MQBO)}

The mixture of 2-aminophenol ( $0.11 \mathrm{~g}, 1 \mathrm{mmol}), \mathrm{KOH}(0.057 \mathrm{~g}, 1 \mathrm{mmol})$ and $2 \mathrm{ml}$ of DMSO were taken in a $100 \mathrm{ml}$ borosil beaker. 2-Chloro-6-methylquinoline-3-carbaldehyde (1 mmol, $0.314 \mathrm{~g}$ ) and a pinch of KI were then added. The mixture was irradiated for about two minutes in a microwave oven. The product was then hydrolyzed by pouring into icecold water. The final product separated as a solid on acidification with dilute $\mathrm{HCl}$ was then filtered, dried and purified (Scheme 2).

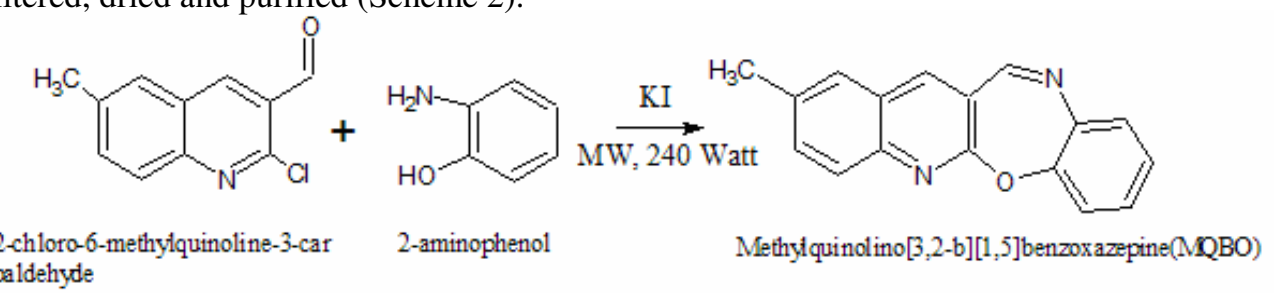

Scheme 2. Preparation of Methylquinolino[3,2-b][1,5]benzoxazepine(MQBO)

\section{Cobalt(II) and Nickel(II) complex of $M Q B D$ and $M Q B O$}

The hot solution $(0.5 \mathrm{mmol}, 50 \mathrm{ml})$ of metal(II) chloride was slowly added to $50 \mathrm{ml}$ of hot ethanolic solution of the ligand $(1.0 \mathrm{mmol})$ with continuous stirring. The reaction mixture was warmed on a water bath at $60-70{ }^{\circ} \mathrm{C}$ for about 2 hours. The precipitate obtained was filtered, washed several times with absolute alcohol, finally with ether and dried.

\section{Cadmium (II) and Zinc (II) complexes of $M Q B D$ and $M Q B O$}

The ethanolic solution of divalent metal salt $(2.5 \mathrm{mmol})$ was added to a solution of the ligand $(2.5 \mathrm{mmol})$ in ethanol $(10 \mathrm{ml})$. The reaction was stirred for $24 \mathrm{~h}$ at room temperature. The solid formed was filtered and dried under vacuum.

\section{Results and Discussion}

\section{Stoichiometry}

The complexes are microcrystalline coloured powder, whose melting points are higher than the pure ligand. They are stable at room temperature and are insoluble in common organic solvents. The elemental analysis data show that they are of the types $\left[\mathrm{ML}_{2} \mathrm{Cl}_{2}\right]$ where $\mathrm{M}=\mathrm{Co}(\mathrm{II}) / \mathrm{Ni}(\mathrm{II}), \quad \mathrm{L}=\mathrm{MQBD} / \mathrm{MQBO}$ and $\left[\mathrm{MLCl}_{2}\right]$ where $\mathrm{M}=\mathrm{Zn}(\mathrm{II}) / \mathrm{Cd}(\mathrm{II})$; $\mathrm{L}=\mathrm{MQBD} / \mathrm{MQBO}$. Low molar conductance values (14.45-27.4 mhos $\mathrm{cm}^{2} \mathrm{~mol}^{-1}$ ) of these complexes indicate their non-electrolytic nature (Table 1).

\section{Magnetic moments}

The room temperature magnetic moment value (Table 1) support octahedral geometry for $\mathrm{Co}(\mathrm{II})$ and $\mathrm{Ni}(\mathrm{II})$ complexes $^{12,13}$. The $\mathrm{Zn}(\mathrm{II})$ and $\mathrm{Cd}(\mathrm{II})$ complexes are diamagnetic due to non availability of unpaired electrons ${ }^{14}$.

\section{Spectral study}

The octahedral Co(II) complexes exhibit three bands at 13380-14368 $\mathrm{cm}^{-1}, 14480-15020 \mathrm{~cm}^{-}$ ${ }^{1}$ and 16484-16490 $\mathrm{cm}^{-1}$ pertaining to ${ }^{4} \mathrm{~T}_{1 \mathrm{~g}}(\mathrm{~F}) \rightarrow{ }^{4} \mathrm{~T}_{2 \mathrm{~g}}(\mathrm{~F})\left(v_{1}\right),{ }^{4} \mathrm{~T}_{1 \mathrm{~g}}(\mathrm{~F}) \rightarrow{ }^{4} \mathrm{~A}_{2 \mathrm{~g}}(\mathrm{~F})\left(v_{2}\right)$ and ${ }^{4} \mathrm{~T}_{1 \mathrm{~g}}(\mathrm{~F}) \rightarrow{ }^{4} \mathrm{~T}_{1 \mathrm{~g}}(\mathrm{P}) \quad\left(v_{3}\right)$ transitions, respectively ${ }^{15}$. The absorption spectra of $\mathrm{Ni}(\mathrm{II})$ complexes show two bands at $12618-16253 \mathrm{~cm}^{-1}$ and $23266-28021 \mathrm{~cm}^{-1}$ due to ${ }^{3} \mathrm{~A}_{2 \mathrm{~g}(\mathrm{~F})} \rightarrow$ ${ }^{3} \mathrm{~T}_{1 \mathrm{~g}(\mathrm{~F})} \quad\left(\mathrm{V}_{2}\right)$ and ${ }^{3} \mathrm{~A}_{2 \mathrm{~g}(\mathrm{~F})} \rightarrow{ }^{3} \mathrm{~T}_{1 \mathrm{~g}(\mathrm{P})}\left(\mathrm{V}_{3}\right)$ transitions respectively supporting the octahedral stereochemistry ${ }^{16}$. The absorption spectra of $\mathrm{Zn}(\mathrm{II})$ and $\mathrm{Cd}(\mathrm{II})$ complexes show no bands due to $\mathrm{d}-\mathrm{d}$ transition. This phenomenon is natural as there is no possibility of transition due 
to non availability of empty d-orbital ${ }^{17}$. By considering spectral data, the tetrahedral ${ }^{18}$ and square planar geometry ${ }^{19}$ have been proposed for $\mathrm{Cd}(\mathrm{II})$ and $\mathrm{Zn}(\mathrm{II})$ complexes, respectively.

Table 1. Physical constants of ligands and its complexes.

\begin{tabular}{|c|c|c|c|c|c|c|c|c|c|}
\hline \multirow[t]{2}{*}{ Compound } & \multirow{2}{*}{$\begin{array}{l}0 \\
\frac{\partial}{0} \\
\vdots\end{array}$} & \multicolumn{5}{|c|}{ Found (Calcd) \% } & \multirow{2}{*}{ 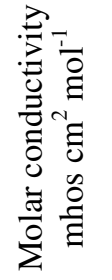 } & \multirow{2}{*}{ 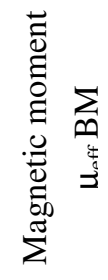 } & \multirow{2}{*}{ 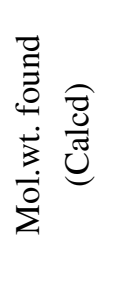 } \\
\hline & & $\mathrm{C}$ & $\mathrm{H}$ & $\mathrm{N}$ & M & $\mathrm{Cl}$ & & & \\
\hline MQBD & 74 & $\begin{array}{c}78.89 \\
(78.74)\end{array}$ & $\begin{array}{c}5.25 \\
(5.05)\end{array}$ & $\begin{array}{c}16.35 \\
(16.20)\end{array}$ & -- & -- & -- & -- & $\begin{array}{c}256.21 \\
(259.30)\end{array}$ \\
\hline MQBO & 76 & $\begin{array}{c}78.65 \\
(78.44)\end{array}$ & $\begin{array}{c}4.83 \\
(4.65)\end{array}$ & $\begin{array}{c}11.01 \\
(10.76)\end{array}$ & -- & -- & -- & -- & $\begin{array}{c}257.26 \\
(260.29)\end{array}$ \\
\hline$\left[\mathrm{Co}(\mathrm{MQBD})_{2} \mathrm{Cl}_{2}\right]$ & 82 & $\begin{array}{c}60.27 \\
(62.98)\end{array}$ & $\begin{array}{c}4.23 \\
(4.04)\end{array}$ & $\begin{array}{c}13.01 \\
(12.96)\end{array}$ & $\begin{array}{c}9.20 \\
(9.09)\end{array}$ & $\begin{array}{c}11.21 \\
(10.93)\end{array}$ & 22.4 & 4.84 & $\begin{array}{c}645.35 \\
(648.44)\end{array}$ \\
\hline$\left[\mathrm{Ni}(\mathrm{MQBD})_{2} \mathrm{Cl}_{2}\right]$ & 75 & $\begin{array}{c}64.4 \\
(63.0)\end{array}$ & $\begin{array}{c}4.2 \\
(4.0)\end{array}$ & $\begin{array}{c}13.0 \\
(12.9)\end{array}$ & $\begin{array}{c}8.9 \\
(9.0)\end{array}$ & $\begin{array}{c}11.1 \\
(10.9)\end{array}$ & 23.4 & 2.99 & $\begin{array}{c}642.89 \\
(648.21)\end{array}$ \\
\hline$\left[\mathrm{Cd}(\mathrm{MQBD}) \mathrm{Cl}_{2}\right]$ & 82 & $\begin{array}{c}42.89 \\
(46.31)\end{array}$ & $\begin{array}{c}2.86 \\
(2.96)\end{array}$ & $\begin{array}{c}9.58 \\
(9.48)\end{array}$ & $\begin{array}{r}26.41 \\
(25.40\end{array}$ & $\begin{array}{c}16.15 \\
(16.02)\end{array}$ & 14.52 & -- & $\begin{array}{c}439.87 \\
(442.62)\end{array}$ \\
\hline$\left[\mathrm{Zn}(\mathrm{MQBD}) \mathrm{Cl}_{2}\right]$ & 75 & $\begin{array}{c}55.38 \\
(57.61)\end{array}$ & $\begin{array}{c}3.35 \\
(3.31)\end{array}$ & $\begin{array}{c}10.72 \\
(10.62)\end{array}$ & $\begin{array}{r}16.61 \\
(16.53\end{array}$ & $\begin{array}{c}17.86 \\
(17.92)\end{array}$ & 15.25 & -- & $\begin{array}{c}392.35 \\
(395.60)\end{array}$ \\
\hline$\left[\mathrm{Co}(\mathrm{MQBO})_{2} \mathrm{Cl}_{2}\right]$ & 82 & $\begin{array}{c}60.68 \\
(62.78)\end{array}$ & $\begin{array}{c}3.68 \\
(3.72)\end{array}$ & $\begin{array}{c}8.75 \\
(8.61)\end{array}$ & $\begin{array}{c}8.96 \\
(9.06)\end{array}$ & $\begin{array}{c}11.01 \\
(10.90)\end{array}$ & 22.5 & 4.87 & $\begin{array}{c}646.54 \\
(650.41)\end{array}$ \\
\hline$\left[\mathrm{Ni}(\mathrm{MQBO})_{2} \mathrm{Cl}_{2}\right]$ & 80 & $\begin{array}{c}60.2 \\
(62.8)\end{array}$ & $\begin{array}{c}3.5 \\
(3.7)\end{array}$ & $\begin{array}{c}8.8 \\
(8.6)\end{array}$ & $\begin{array}{c}9.1 \\
(9.0)\end{array}$ & $\begin{array}{c}11.1 \\
(10.9)\end{array}$ & 27.4 & 3.12 & $\begin{array}{c}645.89 \\
(650.17)\end{array}$ \\
\hline$\left[\mathrm{Cd}(\mathrm{MQBO}) \mathrm{Cl}_{2}\right]$ & 82 & $\begin{array}{c}43.31 \\
(46.03)\end{array}$ & $\begin{array}{c}2.81 \\
(2.73)\end{array}$ & $\begin{array}{c}6.28 \\
(6.31)\end{array}$ & $\begin{array}{r}25.36 \\
(25.34\end{array}$ & $\begin{array}{c}15.83 \\
(15.98)\end{array}$ & 14.45 & -- & $\begin{array}{c}440.24 \\
(443.60)\end{array}$ \\
\hline$\left[\mathrm{Zn}(\mathrm{MQBO}) \mathrm{Cl}_{2}\right]$ & 72 & $\begin{array}{c}49.52 \\
(51.48)\end{array}$ & $\begin{array}{c}3.10 \\
(3.05)\end{array}$ & $\begin{array}{c}7.16 \\
(7.06)\end{array}$ & $\begin{array}{r}16.58 \\
(16.49\end{array}$ & $\begin{array}{c}17.56 \\
(17.88)\end{array}$ & 24.56 & -- & $\begin{array}{c}393.54 \\
(396.58)\end{array}$ \\
\hline
\end{tabular}

\section{IR Spectra}

The ligand MQBD shows bands at $1662 \mathrm{~cm}^{-1}$ and $3332 \mathrm{~cm}^{-1}$ due to $v(\mathrm{C}=\mathrm{N})$ and $v(\mathrm{NH})$ vibrations respectively ${ }^{20}$. These bands are shifting in the complexes indicates the coordination of nitrogen atom of quinoline and azepine moiety with the metal ions. The IR spectra of MQBO showed absorption bands at $1025 \mathrm{~cm}^{-1}$ and $1653 \mathrm{~cm}^{-1}$ for $v(\mathrm{COC})$, $v(\mathrm{C}=\mathrm{N})$ respectively ${ }^{21}$. The negative shift of these bands in the complexes indicates the sites of coordination are nitrogen and oxygen atoms quinoline and azepine rings, respectively. The important IR spectral data are shown in Table 2. 


\section{${ }^{1} H$ NMR spectra}

All the compounds show the ${ }^{1} \mathrm{H}$ NMR signals for different kinds of protons at their respective positions. The data are shown in Table 2. The ${ }^{1} \mathrm{H}$ NMR spectra of the ligand MQBD exhibit a singlets at $10.80 \delta(\mathrm{s}, \mathrm{N}-\mathrm{H})$ and $8.6 \delta(\mathrm{s}, \mathrm{H}-\mathrm{C}=\mathrm{N})$. The $1 \mathrm{H}$ NMR spectra of complexes slightly changed compared to those of the corresponding ligand, and the signals appeared downfield, as expected, due to the coordination of nitrogen atoms to the metal ion ${ }^{22-24}$. ${ }^{1} \mathrm{H}$ NMR spectrum of MQBO ligand showed signals at $\delta 8.4(\mathrm{~s}, 1 \mathrm{H}, \mathrm{H}-\mathrm{C}=\mathrm{N}), 7.3-$ $8.0(\mathrm{~m}, 11 \mathrm{H}, \mathrm{Ar}-\mathrm{H})$ and $2.6\left(\mathrm{~s}, 3 \mathrm{H}, \mathrm{CH}_{3}\right)$. In the spectra of complexes, all signals remained at same position except the signal of $\mathrm{H}-\mathrm{C}=\mathrm{N}$. This is probably due to the coordinating effect of the azepine oxygen atom.

Table 2. The IR and ${ }^{1} \mathrm{H}$ NMR spectral data of ligands and complexes.

\begin{tabular}{|c|c|c|c|c|c|c|}
\hline Compound & $v(\mathrm{C}=\mathrm{N})$ & $\begin{array}{l}\text { Infrare } \\
v(\mathrm{NH})\end{array}$ & $\begin{array}{l}\text { d spectral } \\
v(\text { COC })\end{array}$ & $\begin{array}{l}\text { data } \\
v \mathrm{M}-\mathrm{N}\end{array}$ & $v \mathrm{M}-\mathrm{X}$ & $\begin{array}{c}{ }^{1} \mathrm{H} \text { NMR spectral data } \\
\delta, \mathrm{ppm}\end{array}$ \\
\hline MQBD & 1662 & 3332 & -- & -- & -- & $\begin{array}{c}10.80(\mathrm{~s}, 1 \mathrm{H}, \mathrm{NH}), 8.6(\mathrm{~s}, 1 \mathrm{H}, \mathrm{H}- \\
\mathrm{C}=\mathrm{N}), 7.1-8.2(\mathrm{~m}, 11 \mathrm{H}, \mathrm{Ar}-\mathrm{H}) \\
2.7\left(\mathrm{~s}, 3 \mathrm{H}, \mathrm{CH}_{3}\right)\end{array}$ \\
\hline MQBO & 1653 & -- & 1025 & -- & -- & $\begin{array}{c}8.4(\mathrm{~s}, 1 \mathrm{H}, \mathrm{H}-\mathrm{C}=\mathrm{N}), 7.3-8.0(\mathrm{~m} \\
11 \mathrm{H}, \mathrm{Ar}-\mathrm{H}), 2.6\left(\mathrm{~s}, 3 \mathrm{H}, \mathrm{CH}_{3}\right)\end{array}$ \\
\hline$\left[\mathrm{Co}(\mathrm{MQBD})_{2} \mathrm{Cl}_{2}\right]$ & 1616 & 3318 & -- & 438 & 352 & $\begin{array}{c}10.95(\mathrm{~s}, 1 \mathrm{H}, \mathrm{NH}), 8.4(\mathrm{~s}, 1 \mathrm{H}, \mathrm{H}- \\
\mathrm{C}=\mathrm{N}), 7.2-8.8(\mathrm{~m}, 9 \mathrm{H}, \mathrm{Ar}-\mathrm{H})\end{array}$ \\
\hline$\left[\mathrm{Co}(\mathrm{MQBO})_{2} \mathrm{Cl}_{2}\right]$ & 1614 & -- & 996 & 454 & 364 & $\begin{array}{c}8.3(\mathrm{~s}, 1 \mathrm{H}, \mathrm{H}-\mathrm{C}=\mathrm{N}) \\
7.5-8.9(\mathrm{~m}, 9 \mathrm{H}, \mathrm{Ar}-\mathrm{H})\end{array}$ \\
\hline$\left[\mathrm{Ni}(\mathrm{MQBD})_{2} \mathrm{Cl}_{2}\right]$ & 1622 & 3312 & -- & 468 & 252 & $\begin{array}{c}10.90(\mathrm{~s}, 1 \mathrm{H}, \mathrm{NH}), 8.4(\mathrm{~s}, 1 \mathrm{H}, \mathrm{H}- \\
\mathrm{C}=\mathrm{N}), 7.2-8.8(\mathrm{~m}, 9 \mathrm{H}, \mathrm{Ar}-\mathrm{H})\end{array}$ \\
\hline$\left[\mathrm{Ni}(\mathrm{MQBO})_{2} \mathrm{Cl}_{2}\right]$ & 1630 & -- & 994 & 450 & 260 & $\begin{array}{c}\text { 8.1 (s, 1H, H-C=N), } \\
7.5-8.9(\mathrm{~m}, 9 \mathrm{H}, \mathrm{Ar}-\mathrm{H})\end{array}$ \\
\hline$\left[\mathrm{Cd}(\mathrm{MQBD}) \mathrm{Cl}_{2}\right]$ & 1612 & 3300 & -- & 432 & 348 & $\begin{array}{c}10.85(\mathrm{~s}, 1 \mathrm{H}, \mathrm{NH}), 8.3(\mathrm{~s}, 1 \mathrm{H}, \mathrm{H}- \\
\mathrm{C}=\mathrm{N}), 7.2-7.8(\mathrm{~m}, 9 \mathrm{H}, \mathrm{Ar}-\mathrm{H})\end{array}$ \\
\hline$\left[\mathrm{Cd}(\mathrm{MQBO}) \mathrm{Cl}_{2}\right]$ & 1610 & -- & 996 & 430 & 362 & $\begin{array}{c}8.2(\mathrm{~s}, 1 \mathrm{H}, \mathrm{H}-\mathrm{C}=\mathrm{N}) \\
7.1-8.0(\mathrm{~m}, 9 \mathrm{H}, \mathrm{Ar}-\mathrm{H})\end{array}$ \\
\hline$\left[\mathrm{Zn}(\mathrm{MQBD}) \mathrm{Cl}_{2}\right]$ & 1624 & 2990 & -- & 428 & 348 & $\begin{array}{c}10.90(\mathrm{~s}, 1 \mathrm{H}, \mathrm{NH}), 8.1(\mathrm{~s}, 1 \mathrm{H}, \mathrm{H}- \\
\mathrm{C}=\mathrm{N}), 7.2-7.8(\mathrm{~m}, 9 \mathrm{H}, \mathrm{Ar}-\mathrm{H})\end{array}$ \\
\hline$\left[\mathrm{Zn}(\mathrm{MQBO}) \mathrm{Cl}_{2}\right]$ & 1614 & -- & 1002 & 430 & 350 & $\begin{array}{c}8.0(\mathrm{~s}, 1 \mathrm{H}, \mathrm{H}-\mathrm{C}=\mathrm{N}) \\
7.5-8.9(\mathrm{~m}, 9 \mathrm{H}, \mathrm{Ar}-\mathrm{H})\end{array}$ \\
\hline
\end{tabular}

Antibacterial Activity

The comparison of inhibition zone values for the metal complexes (Table 3) reveals that the antimicrobial activity could be mainly due to the structure of the complexes and also the oxidation state of the metal ions. These results must be directly related to the greater biological activity exhibited by the square planar $\mathrm{Zn}$ (II) complexes compared to the tetrahedral Cd(II) and octahedral Co(II), Ni(II) complexes.

A possible explanation for the high toxicity of metal complexes can be explained as follows. The increase in the activity of metal complexes may be due to effect of metal ions on the normal cell process. The polarity of metal ion is considerably reduced on chelation which is mainly because of partial sharing of its positive charge with a donor groups and 
possibly $\pi$-electron delocalization over the whole molecule. Such molecule increases the liphophilic character of the metal complexes which probably leads to break down of permeability barrier of the cells resulting in interference with normal cell process ${ }^{25}$. Better activities of the metal complexes as compared to free ligand could also be understood in terms of chelation theory ${ }^{26}$, which explains that a decrease in polarizability of the metal could enhance the liphophilicity of the complexes.

Table 3. Inhibition zone of bacterial growth $(\mathrm{mm})$

\begin{tabular}{lcccccc}
\hline \multirow{2}{*}{ Compound } & \multicolumn{3}{c}{ P.aerugenosa } & \multicolumn{3}{c}{ S.aureus } \\
& $0.1 \%$ & $0.2 \%$ & $0.3 \%$ & $0.1 \%$ & $0.2 \%$ & $0.3 \%$ \\
\hline MQBD & 1.2 & 1.6 & 2.8 & 1.4 & 1.8 & 3.0 \\
MQBO & 1.1 & 2.0 & 3.0 & 1.3 & 1.6 & 2.9 \\
{$\left[\mathrm{Zn}(\mathrm{MQBD}) \mathrm{Cl}_{2}\right]$} & 2.2 & 2.7 & 4.3 & 2.3 & 3.1 & 5.1 \\
{$\left[\mathrm{Cd}(\mathrm{MQBD}) \mathrm{Cl}_{2}\right]$} & 1.8 & 2.4 & 3.9 & 2.0 & 2.8 & 4.3 \\
{$\left[\mathrm{Co}(\mathrm{MQBD})_{2} \mathrm{Cl}_{2}\right]$} & 1.6 & 2.0 & 3.4 & 1.7 & 2.3 & 3.6 \\
{$\left[\mathrm{Ni}(\mathrm{MQBD})_{2} \mathrm{Cl}_{2}\right]$} & 1.5 & 2.0 & 3.2 & 1.7 & 2.2 & 3.5 \\
{$\left[\mathrm{Zn}(\mathrm{MQBO}) \mathrm{Cl}_{2}\right]$} & 1.8 & 3.2 & 4.2 & 2.1 & 2.9 & 4.3 \\
{$\left[\mathrm{Cd}(\mathrm{MQBO}) \mathrm{Cl}_{2}\right]$} & 1.6 & 2.9 & 3.7 & 2.0 & 2.6 & 3.9 \\
{$\left[\mathrm{Co}(\mathrm{MQBO})_{2} \mathrm{Cl}_{2}\right]$} & 1.5 & 2.6 & 3.5 & 1.6 & 2.2 & 3.4 \\
{$\left[\mathrm{Ni}(\mathrm{MQBO})_{2} \mathrm{Cl}_{2}\right]$} & 1.5 & 2.5 & 3.5 & 1.6 & 2.1 & 3.3 \\
\hline
\end{tabular}

\section{Antifungal activity}

The percentage inhibition values of fungicidal growth are recorded in Table 4. The screening data clearly shows that the complexes were more toxic than their parent ligand under identical experimental conditions and as the concentration of the complexes increases the inhibition of the fungal growth increases.

Table 4. Percentage inhibition of fungicidal growth.

\begin{tabular}{lcccccccccc}
\hline \multirow{2}{*}{ Compound } & \multicolumn{3}{c}{ C. albicans } & \multicolumn{3}{c}{ A. niger } & \multicolumn{4}{c}{ A. flavus } \\
& $0.1 \%$ & $0.2 \%$ & $0.3 \%$ & $0.1 \%$ & $0.2 \%$ & $0.3 \%$ & $0.1 \%$ & $0.2 \%$ & $0.3 \%$ \\
\hline MQBD & 11.2 & 13.8 & 18.3 & 10.3 & 13.4 & 20.2 & 9.8 & 13.1 & 24.2 \\
MQBO & 10.3 & 12.9 & 16.9 & 8.8 & 11.9 & 18.6 & 7.8 & 11.8 & 22.3 \\
{$\left[\mathrm{Zn}(\mathrm{MQBD}) \mathrm{Cl}_{2}\right]$} & 13.2 & 20.5 & 29.6 & 13.2 & 16.9 & 23.2 & 12.4 & 15.2 & 27.5 \\
{$\left[\mathrm{Cd}(\mathrm{MQBD}) \mathrm{Cl}_{2}\right]$} & 12.9 & 18.5 & 25.6 & 12.1 & 16.0 & 22.4 & 11.3 & 14.3 & 26.3 \\
{$\left[\mathrm{Co}(\mathrm{MQBD})_{2} \mathrm{Cl}_{2}\right]$} & 12.7 & 15.9 & 23.0 & 11.3 & 14.5 & 21.5 & 10.6 & 13.6 & 25.2 \\
{$\left[\mathrm{Ni}(\mathrm{MQBD})_{2} \mathrm{Cl}_{2}\right]$} & 11.6 & 15.2 & 22.1 & 11.0 & 14.3 & 21.3 & 10.5 & 13.5 & 25.1 \\
{$\left[\mathrm{Zn}(\mathrm{MQBO}) \mathrm{Cl}_{2}\right]$} & 12.3 & 19.8 & 28.5 & 11.5 & 14.9 & 21.1 & 10.2 & 14.4 & 25.3 \\
{$\left[\mathrm{Cd}(\mathrm{MQBO}) \mathrm{Cl}_{2}\right]$} & 11.8 & 17.8 & 25.2 & 10.5 & 14.1 & 20.1 & 9.1 & 13.5 & 24.6 \\
{$\left[\mathrm{Co}(\mathrm{MQBO})_{2} \mathrm{Cl}_{2}\right]$} & 11.1 & 15.6 & 22.0 & 9.8 & 13.0 & 19.3 & 8.6 & 12.9 & 23.4 \\
{$\left[\mathrm{Ni}(\mathrm{MQBO})_{2} \mathrm{Cl}_{2}\right]$} & 11.1 & 14.9 & 21.5 & 9.7 & 12.9 & 19.2 & 8.5 & 12.8 & 23.2 \\
\hline
\end{tabular}

\section{Acknowledgement}

We thank the Head of the Department of Industrial Chemistry, Kuvempu University, Shimoga, for the provided laboratory facilities. One of the authors (B. Basavaraju) wishes to acknowledge financial support from Mr. G.M. Lingaraju, Secretary, GM Institute of Technology, Davangere-577 006, Karnataka, India. 


\section{References}

1. Chiari E, Oliveira AB, Prado MAF, Alves RJ, Galvno LM and Araujo FG, J.Antimicrob.Agents Chemother., 1996,40,613.

2. Sahy NS, Pal C, Mandal NB, Banerjee S, Raha M, Kundu AP, Basu A, Ghosh M, Roy K and Bandopadhyay, Bioorg.Med.Chem. 2002, 10,1687.

3. Kim K, Kim H, Park K and Cho K, J.Korean Chem.Soc. 1998,42,236.

4. Jonckers TH, Miert SV, Cimanga K, Bailly C, Colson P, Gillet MC and Pauw D, J.Med.Chem., 2002,45(16),3497.

5. Dassonneville L, Lansiaux A, Wattelet A, Wattez N, Mahievu C and Miert SV. Eur.J.Pharmacol, 2000,409(1),9.

6. Godlewska J, Badowoska K, Ramza J, Kaczmarek L, Peczynska-Czoch and Opolski A, Radiol Oncol., 2004,38(2),137.

7. O'Neill PM, Bray PG, Hawley SR, Ward SA and Park BK, Pharmacol.Ther., 1998,77(1),29.

8. $\quad$ Foley M and Tilley L, Pharmacol.Ther., 1998,79(1),55.

9. Fahy PC and Persley GJ, Bacterial Diseases, Diagnostic Guide, New York, Academic Press, 1983.

10. Batemann E, U.S.Depat. Of Agril Tech. Bull., 1933,1,,346.

11. Vincent J, Nature, 1947,159,580.

12. Figgis BN and Lewis J, Prog.Inorg.Chem., 1964,6,37.

13. Lewis $\mathbf{J}$ and Wilkinson RG, Modern Coorodination Chemistry, Interscience, New York, 1960.

14. Desai RM, Shah MK and Shah VH, E-j.Chem., 2006, 3(12),137.

15. Huheey JE, Inorganic Chemisitry: Principles of Structure and Reactivity, NewYork, Harper and Row, 1980.

16. Iftikhar K, Aravind SM, Ali SM and N.Ahmed, Indian J.Chem., 1987,25A,170.

17. Zhang QL, Liu JH, Ren XZ, Xu H, Liu JZ and Liang-Nian Ji. J.Inorg. Biochem., 2003,95,194.

18. Sastri CV, Eswaramoorthy D, Griribabu L and Maiya BG, J.Inorg.Biochem., 2003,94,138.

19. Raghu N.Prasad and Mala Mathur, J.Serb.Chem.Soc., 2002,67(12),825.

20. Kalluraya B, Gururaja R and Ganesha Rai, Indian J.Chem., 2003,42B,211.

21. Bhojya Naik HS, Chetana PR and Revanasiddappa HD, J Indian Che.Soc., 2002,79, 955.

22. Gupta A, Sirohi R, Shastri S and Kishore D, J.Indian Chem.Soc., 2004,81,163.

23. S.Sampath Kumar and S.P.Rajendran, Asian J.Chem., 2004, 6, 3.

24. Mogilaiah K, Prasanthi M and Vidya K, Indian J.Chem., 2004,43B,2641.

25. Ramappa PG and Somashekarappa KG, J.Inorg.Biochem., 1994,55,13.

26. Srivastava RS, Inorg.Chim.Acta., 1981,56,L65. 


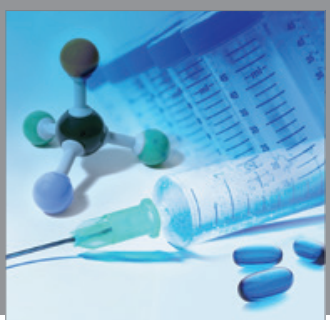

International Journal of

Medicinal Chemistry

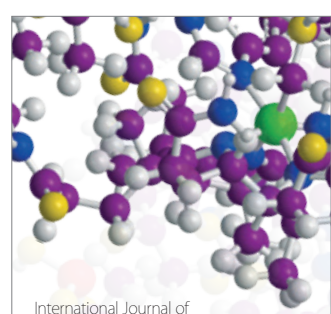

Carbohydrate Chemistry

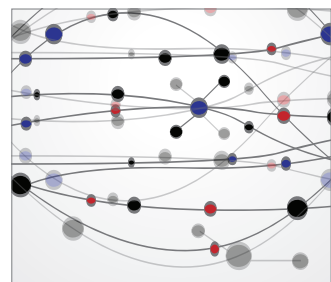

The Scientific World Journal
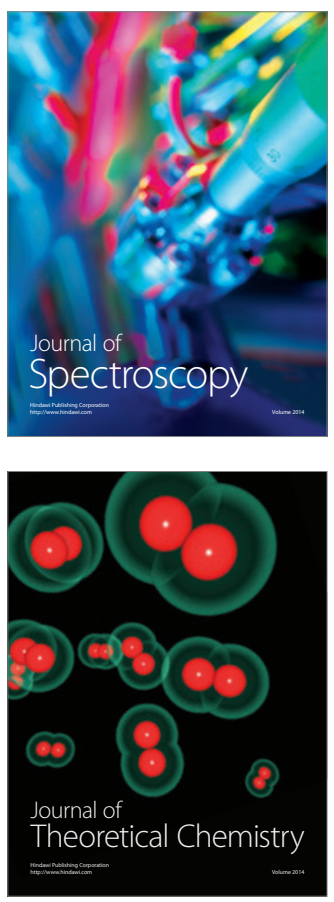
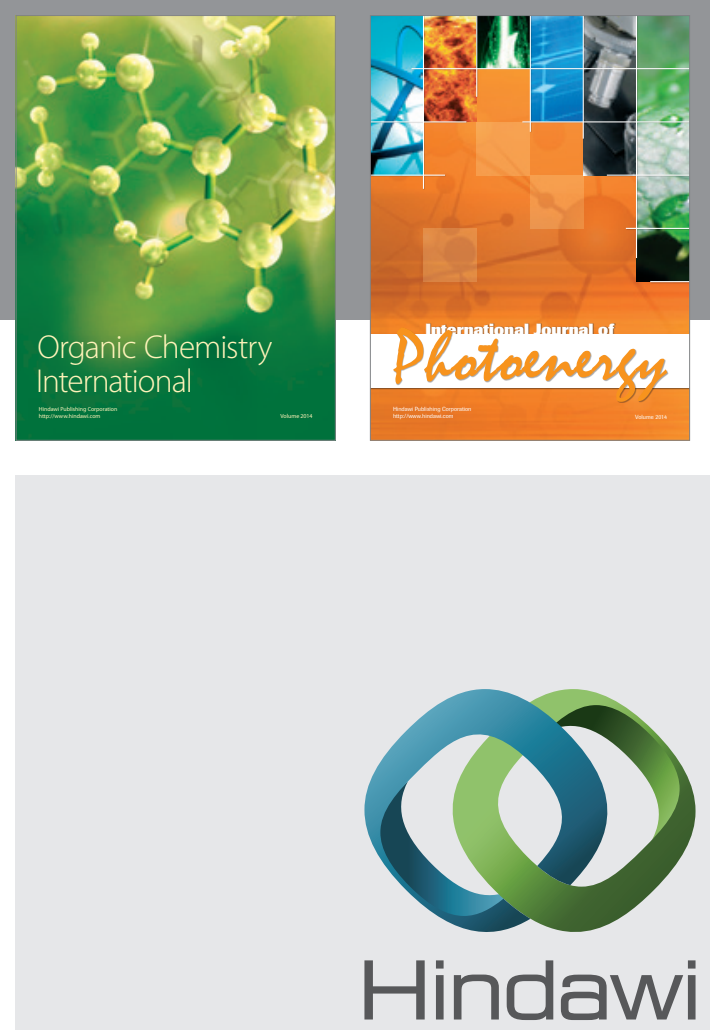

Submit your manuscripts at

http://www.hindawi.com
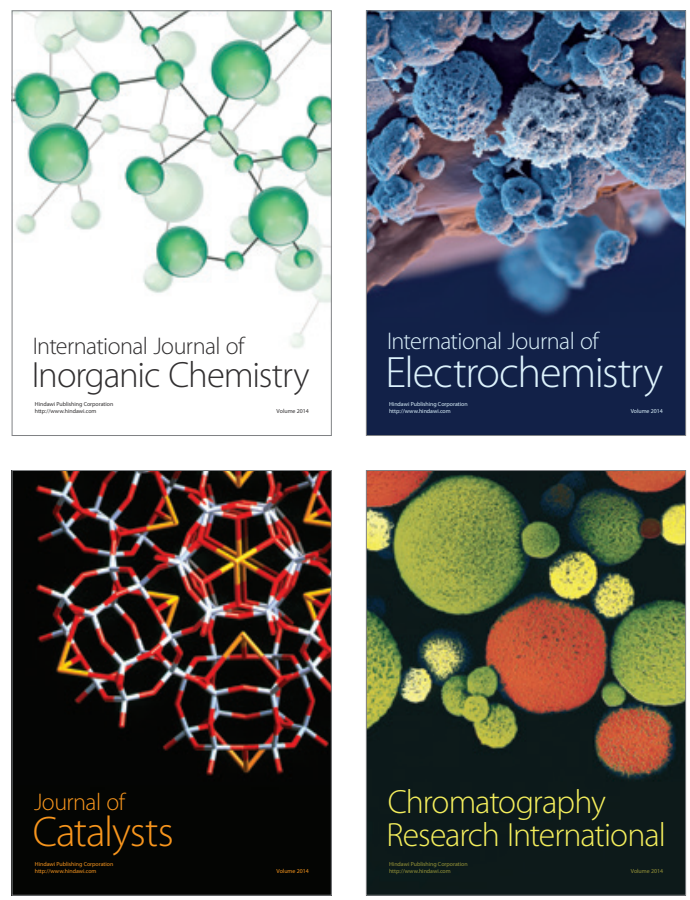
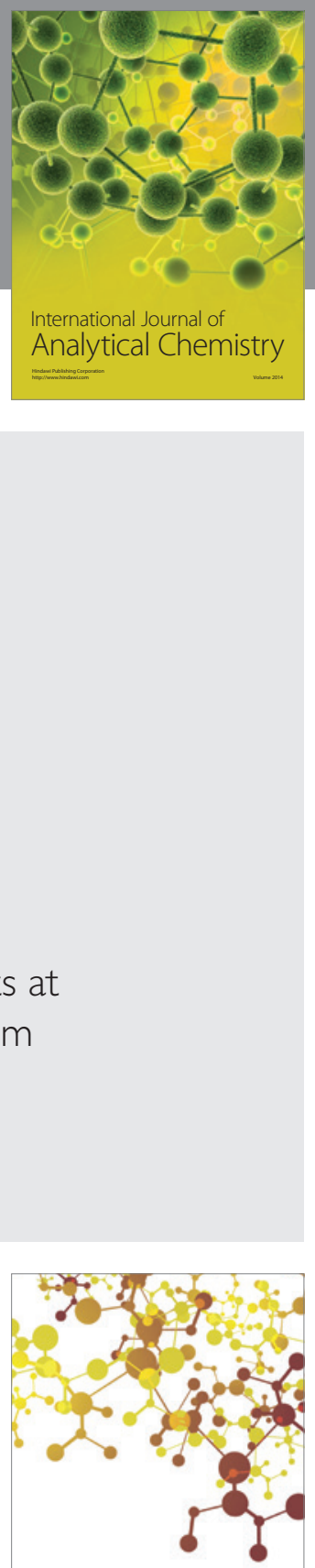

Journal of

Applied Chemistry
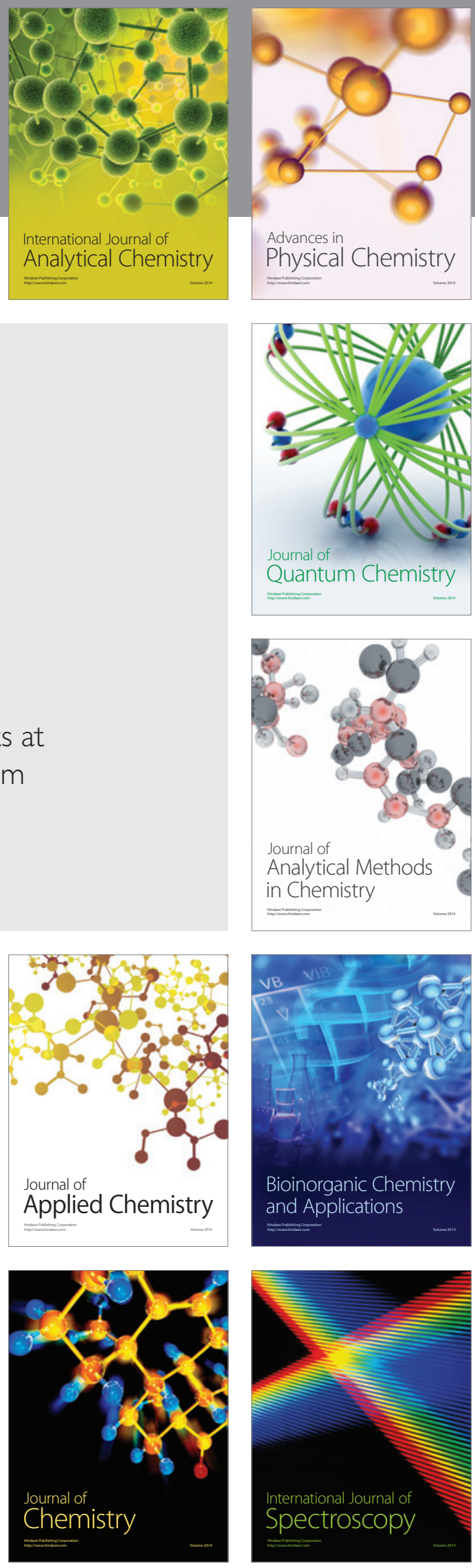